\title{
Designing Scientific Writing Syllabus for Undergraduate Student
}

\author{
Afi Ni'amah'1 , Ika Lusi Kristanti ${ }^{2}$ \\ 1,2 English Education Department, Sekolah Tinggi Keguruan dan IImu Pendidikan PGRI \\ Jombang, Jombang, Indonesia
}

Q afi.niamah@stkipjb.ac.id

\begin{abstract}
Applicable syllabus is necessary in teaching English writing. Enabling undergraduate students to write in English needs wellorganized and appropriate plan that students have less problem in writing. This study is aimed to design topics in Scientific Writing syllabus for undergraduate students in composing research article. This study implemented Design and Development Research (DDR) with qualitative method. In designing syllabus, DDR is used to establish product in providing research article writing. Considering the applicability of product, Analyze-Design-Develop-ImplementEvaluate (ADDIE) model of Dick and Carey is used. The result indicates that there are five significant topics in designing Scientific Writing syllabus. ADDIE model can be implemented in designing syllabus based on the students' problem. It is better for lecturers to implement the model in designing syllabus. However, the implementation step can be done by considering students' need analysis. By implementing the step, in writing class then the product is significantly applicable.
\end{abstract}

\section{KEYWORDS:}

ADDIE, Scientific writing, syllabus, undergraduate students.

\section{Introduction}

Appropriate syllabus is very needed in each course such as writing. Writing course is one of courses that has great influence in creating article. Enabling undergraduate students to write in English needs well-organized and appropriate plan. Lecturers must encourage undergraduate students to compose understandable sentences in expressing their ideas in an article. According to UU number. 12/2012 about higher education level, article is a systematic activity done scientifically for the sake of information, data, and knowledge related to hypothesis. In addition, it is explained in chapter one that an article is composed based on a research as one of academic society's obligation to fulfill Tri Dharma. 
The obligation is also supported by explanation on chapter two of UU number. $12 / 2012$.

Undergraduate students' confusion in composing an article are an essential problem. Thus, it is necessary to design Scientific Writing syllabus which tackles on composing a research article. A research article is one of documents used in academic writing among books and books report, translation, essays, conference paper, academic journal, dissertation and thesis, abstract, and explication (Bailey, 2015). By composing research article, the students expose particular contribution based on their research procedures and results. Publication is the most immediate means in realizing the contribution, and most scientists are motivated as well as satisfied (Mack, 2018). In addition, scholars are required to publish their scientific work in a trustworthy journal.

Undergraduate students' research articles in this study have different steps with that of Slade's but based on the Institution's Guideline. There are six steps proposed by (Slade, 2000) to write scientific article: topic, bibliography, information, outlining, drafting, and final draft. Slade's steps has been used and proved students had problem in writing each part of thesis that thesis writing is important on both teachers and students (Han, 2013). Thesis writing is a matter of scientific writing, and comprising research article is too. Han uses Slade's step in solving writing thesis problem that Slade's is worthy considerations in deciding the proper course material for writing.

In case of having better achievement in English learning, some researchers conducted studies on the use of Analyze, Design, Develop, Implement, and Evaluate model step in designing instructional design (Bello, H., \& Aliyu, 2012; Nadiyah, R. S., \& Faaizah, 2015). The use of Analyze, Design, Develop, Implement, and Evaluate model for the sake of learning achievement is appropriate since it is the concept of product improvement to be implemented for persistent learning environment (Branch, 2010). He explains further that the concept of Analyze, Design, Develop, Implement, and Evaluate model is simple but completed with some stimuli that makes it operative. Thus, Analyze, Design, Develop, Implement, and Evaluate model simplifies difficulties of decisive learning environment in correspond to various circumstances, interaction within and between situation. 
Studies which use Analyze, Design, Develop, Implement, and Evaluate model have also been done on developing media (Hidayanto, D. R., Munir, Rahman, E. F., \& Kusnendar, 2017; Wang, Y., \& Guo, 2014) and material (Tang, W.-L. Tsai J.-T. \& Chen, 2017). The studies proved that Analyze, Design, Develop, Implement, and Evaluate model is one of most famous models used to make creative and effective teaching design. Thus, it helps do not only teachers but also instructional designer and content developer in producing an effective instructional design or product.

This study is conducted to design Scientific Writing syllabus for the fifth semester of undergraduate students by using Analyze, Design, Develop, Implement, and Evaluate model. The syllabus is directed to equip undergraduate students with research article writing. In order to get appropriate syllabus, there should be proper steps in designing it. Analyze, Design, Develop, Implement, and Evaluate is an approach of Design and Development Research. There is a specific characteristic of Analyze, Design, Develop, Implement, and Evaluate model which makes the model as the most common used model-each phase is interrelated each other. (Richey, R. C., \& Klein, 2009) found many researchers have implemented Design and Development Research on instructional products, tools and models with both instructional and non-instructional interventions. This study strains the implementation of Design and Development Research on designing syllabus with Analyze, Design, Develop, Implement, and Evaluate model as the approach.

\section{Theoretical Framework}

As a means of written communication, writing should not be deliberated as simply put ideas in the written form. As a matter of fact, there are considerations to communicate in written language. Encouraging learners to write is not as easy as encouraging them to speak. Compare to Elliott, S. L., Fischer, B. A., Grinnell, F., \& Zigmond, (2015), there are only six steps proposed by Slade to write scientific article-topic, bibliography, information, outlining, drafting, and final draft. Slade's steps had been applied by (Han, 2013) in analyzing the status of graduation thesis based on the effective measures and some practical experience by using rubrics. By the result of the study, Han advocates the essential of thesis writing on teachers 
and students. Both thesis writing and research article writing are scientific writing that research article writing is also important.

Writing is an activity of communicating information through letters, words, phrases, and clauses into understandable sentences to show the writer's ideas shared. Arranging understandable sentences in writer's foreign language is not easy thing to do. The writer's information can be easily understood when it is written properly based on appropriate writing steps. A good writing is depended on the desired effect of the writer upon intended readers (Irvin, 2010). It means grammatical correctness is not the most important thing to be considered in writing but the practical purposes and personal experience of writer are.

Enabling EFL students to write in English needs well-organized and appropriate plan. Well-organized plan is meant to decide suitable media and approach in delivering the course to give students learning experience. In achieving the plan, need analysis is needed before designing it. The plan is then outlined in syllabus along with topic, materials, evaluation scheme, and bibliographies. Need analysis is important in designing syllabus for the achievement of learning outcome. It is in line with Dick, W., Carey, L., \& Carey, (2015) model that put 'Analysis' in the first Analyze, Design, Develop, Implement, Evaluate-type model that is followed by Design-Development-Implementation-Evaluation.

The success of an activity in educational field depends on the syllabus designed since it provides the basis of instructional focus and contents. By the syllabus, the lecturer could display the list of topics, optional references and the approximation in achieving the course. The topics listed in syllabus must follow curriculum. ESL writing curriculum empowers teachers in developing ESL students' knowledge structure, and students in applying concept to real-life matters, developing and acquiring problem solving and critical thinking skills (Beckett, G. H., \& Gonzalez, 2004). In contrast to Beckett and Gonzales' study which tends to authorize teachers, this study is disposed to enable and motivate undergraduate students in exploration article writing.

Analyze, Design, Develop, Implement, and Evaluate model of Dick, W., Carey, L., \& Carey, (2015) is used in developing Scientific Writing syllabus. The use of 
Analyze, Design, Develop, Implement, and Evaluate model is has been proven in designing instruction (Bello, H., \& Aliyu, 2012; Nadiyah, R. S., \& Faaizah, 2015; Ozdilek, Z., \& Robeck, 2009), in designing media as well as ease the course builder to act and build multimedia (Hidayanto, D. R., Munir, Rahman, E. F., \& Kusnendar, 2017). In this study, Analyze, Design, Develop, Implement, and Evaluate model is not used to design either instruction or media but create a syllabus that meets the problem solving of undergraduate students' difficulties. The problem solving is displayed in the form of topics can be concluded in syllabus of Scientific Writing course. Further description about Analyze, Design, Develop, Implement, and Evaluate model can be seen in the figure 1.

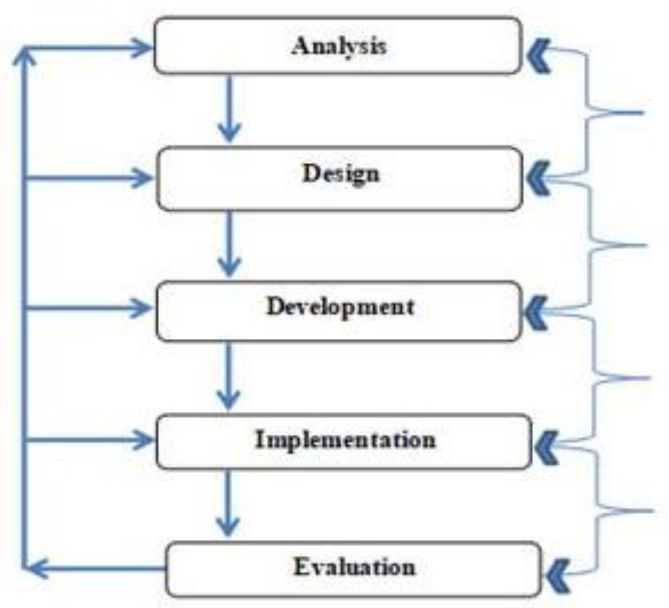

Figure 1 The Analyze, Design, Develop, Implement and Evaluate model (Dick and Carey, 2015)

As CAR which was firstly used in medical treatment and developed in educational improvement, Analyze, Design, Develop, Implement, and Evaluate model was pioneered by the Army but can also be applied in educational expansion. (Branch, 2010) illustrates Analyze, Design, Develop, Implement, evaluate model as a manner of stimulating purposeful learning through the five phases-Analyze, Design, Develop, Implement, and Evaluate (see figure 3.1). Implementing Analyze, Design, Develop, Implement, and Evaluate model in creating creation is the greatest operative device. The effectiveness of Analyze, Design, Develop, Implement, and Evaluate model is proven for the procedure can be used as multifarious circumstances guidance that it is applicable to develop educational invention and learning properties. 
Research article is also called as research paper, one of assignment in academic writing which has to be composed scientifically as one of requirement in joining the inauguration. It is in accordance to Whitaker's assertion that academic writing is any kinds of writing assignment in specific course within academic context for university courses (2009: 2). In case of fulfilling academic writing, the ten principles of Whitaker should be considered in completing writing assignment. Whitaker's principles ease undergraduate students in writing tasks.

There are thirteen steps to be highlighted in writing research article(re)examine the list of authors, construct the tables, figures, and legends, outline the paper, write the first draft, revise the manuscript, write the title and abstract, reread the instructions, prepare the illustrations, get feedback and revise the manuscript, submit the manuscript, deal with reviewers' comments, check the proofs, and celebrate (Elliott, S. L., Fischer, B. A., Grinnell, F., \& Zigmond, 2015). They even advise on consideration in choosing journal and peer review in publishing research article. The consideration implies credible journal is nothing without credible reviewer. In addition, scholars are required to publish their scientific work in a trustworthy journal. In terms of fulfilling inauguration requirements, undergraduate student is obliged to compose an article based on their thesis to be up loaded in the web of the college. In addition, composing an article is able to develop the writer's knowledge since an article figures out a solution of a problem logically by showing a method and validity results to support the conclusion of the research findings. The validity can be agreed as logical data, evidences and references which support the study.

Academic writing needs to have particular organizational structure to express critical thinking on a topic. The organizational structure eases writers in exploring their research finding into research article. There is a symmetrical diagram can be used to show the structure of a research article to facilitate written communication (Glasman-Deal, 2010). The structure of a research article includes abstract, introduction, methodology, results, and discussion. However, each journal publisher has its own structure of research article. 
Considering the students' research articles and Glasman-Deal (2010) research article structure, the inauguration committee then published the guideline of writing research article. Since 2017, the institution published the guideline for all Departments. The guideline involves the structure of research article writing-title, author, sponsor (optional), abstract and key words, introduction, methods, finding, discussion, closing, and references. In case of fulfilling inauguration requirement, the students are obliged to rewrite their theses in the form of inquiry article. Both thesis and inquiry article are included in scientific writing but they are different.

Before mentioning the structure of research article, the guideline highlights the role of writing scientific work-researcher's norms and responsibility. The norms involve written permission, authenticity, respondent's privacy and secret, also obey the role of conducting a research such as data validity and plagiarism. A researcher has also an obligation to interpret the result of the study clearly, responsible to collaborator and institution, be transparent on weakness found, and explain explicitly the advantages and consequence of the study. The advantages and consequence of the research should be directed for the sake of education. In other words, the research is conducted to give contribution to education.

There is limitation on the number of words in writing title, abstract and key words. Among those three points, both the words 'Abstract' and 'Key words' should be written in bold type, not for the title. The title must consist of at least five and not more than sixteen words. Furthermore, it should involve variables which describe the focus of the research. Different with title, the abstract involves problem and object of the study, research method, result of the study, and suggestion. In addition, it consists of at least 150 to 250 words at most with single space on Times New Roman 12. As title and abstract, key words are also limited from three to five words.

In case of fulfilling inauguration requirement, there are two main compulsory things must be fulfilled-the advisor's approval and examiners' acknowledgement on thesis revision. The examiners' signature on the thesis revision sheet means the thesis had been revised based on the examiner's suggestion, including the advisor's approval that the thesis has been compiled properly. After revising the 
thesis, undergraduate students must compose a research article based on the correct work by the advisor's authorization. Hence, the advisor's approval shows that the article had been directed and guided which is proven by the advisor's signature. Unfortunately, does not every advisor confirm whether the article comply with the guideline or not. It means the advisor's signature does not guaranty the conformity of the article to the guideline.

\section{Method}

This study is conducted to develop Scientific Writing syllabus for the fifth semester of undergraduate students. The syllabus is concentrating to equip undergraduate students with research article writing. In order to get appropriate syllabus, there should be steps in designing it. In other words, this study is intended to design a product which is then tested, evaluated, and refined to meet particular educational necessity. The word design involves activities done for the curriculum development in which preliminary and analytical studies used to design and formative evaluation during the activities are ended with implementation of the product (Plomp, 2010).

The preliminary study in this study is finding undergraduate students' distress in research article writing, while the analytical study is analyzing the students' research article to conclude the topics of Scientific Writing syllabus. Considering clear and organized procedures in designing syllabus, Design and Development Research is implemented. It is used to establish a product to provide research article writing. In order to get proper data, this study employs Design and Development Research with qualitative method. In case of designing syllabus, Analyze, Design, Develop, Implement, Evaluate model of Dick \& Carey (2015) is used. The use of Dick and Carey model is displayed in the figure 2. 


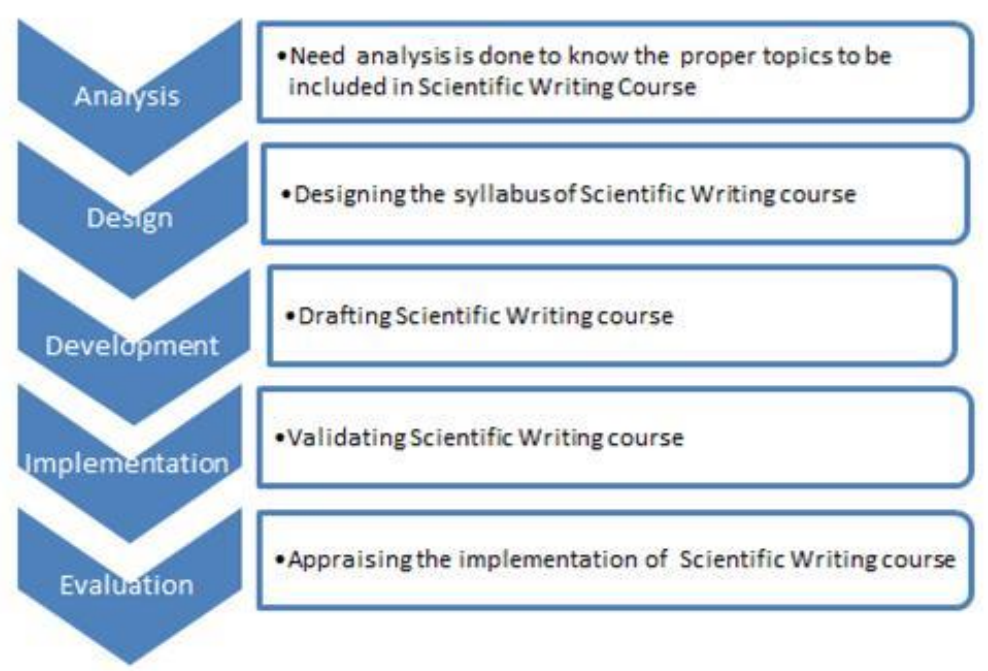

Figure 2 The use of Analyze, Design, Develop, Implement, Evaluate model in designing Scientific Writing syllabus

The model serves a framework of guidance which is appropriate in designing educational products and learning resources. There are five steps as linked-up phase in which each level creates a product. The product of each stage is evaluated before continuing to the next phase. Thus, the product formed in each step decides the improvement of the product on the next procedure that the product is getting better and better in each step.

\section{Participants}

This study tries to formulate Scientific Writing syllabus addressed to the fifth semester of undergraduate students. The syllabus is directed to English Department Students of STKIP PGRI Jombang who role as the participants of this study. The last writing course-Argumentative Writing, is given during their fourth semester. Their next four semesters passed without any writing course. In the seventh semester they begin undergraduate thesis guidance and start the adventure on academic writing. After finishing undergraduate thesis, they are proposed to make a research article based on the thesis. Although they have been guided and experienced in thesis writing, it does not guaranty their ability in writing research article. Both thesis and research article are included in academic writing and scientific works, but each has different characteristics and procedures. In reflecting the occurrence, Scientific Writing syllabus is premeditated. 


\section{Instrument}

In completing the study there are three instruments used, they are document, interview guide and questionnaire. A rubric is also prepared to fit in the organization of undergraduate students' research article to the Institution's Guide. Each aspect is given score to show the quality of undergraduate students' articlethe better mark means the better quality of the article. The total score is obeyed to the range in table 1.

Table 1. The Required Criteria of Undergraduate Students' Article

\begin{tabular}{ccc}
\hline Criteria & Total Score & Mark \\
\hline A & $80,00-100$ & Excellent \\
B & $66,00-79,99$ & Good \\
C & $56,00-65,99$ & Fairly good \\
D & $46,00-55,99$ & Poor \\
E & $0-45,99$ & Very poor \\
\hline
\end{tabular}

\section{Data analysis}

There are three steps in analyzing the data, they are data reduction, data display, and verification or conclusion (Miles, M. B., Huberman, A. M., and Saldana, 2014). The data reduction is held based on the research question. Next, diagram is used to show the relation of data toward the research question. Then, the data and the theory is inter-related to answer the research question. The last step is verification or conclusion. In this step, the researchers draw conclusion and formulated draft of scientific writing syllabus.

The result of need analysis is based on the first instrument (need analysis questionnaire) distributed to the students on the inauguration registration period. Their response is used to interpret prediction on undergraduate students' necessity in uniting research article. The outcome of need analysis is to the line to the interview also. The estimation is then conformed to the upshot of interview and questionnaire given to the students. Based on the first instrument (document), the arrangement of undergraduate students' research article was drawn in a table to be conformed to the Institution's Guide. The table is then conformed to the second 
instrument (interview) and the last instrument (questionnaire). The notes on the students' article are then considered as topics should be included in Scientific Writing syllabus. The topics are then directed to decide the competence, learning outcomes, indicators, teaching and learning activities, and evaluation system. Thus, draft of Scientific Writing syllabus is built. The organization of the students research article can be seen in the following table 2 .

Table 2. The Arrangement of the Students' Research Article

\begin{tabular}{lll}
\hline No & Research Article Structure (RAS) & Note on the RAS \\
\hline 1 & Match to the guideline & The number of abstract word is \\
& 290. \\
& The number of page is less than \\
& the requirement of the guideline. \\
& The total word number does not \\
& approximate the requirement of \\
& the guideline. \\
& The key wore is in the form of \\
& clause, not word(s). \\
\hline
\end{tabular}

\section{Result}

This study is conducted by implementing Analyze, Design, Develop, Implement, and Evaluate model of Dick and Carey that consists of five steps as the acronym. The five steps involve A for Analysis, D for Design, D for Development, I for Implementation, and E for Evaluation. Each step is evaluated to be completed in the next stage. The step makes the product designed on every step is getting better and better that the model is applicable.

\section{Analysis}

Undergraduate students' problem in scientific writing is proven by interview and questionnaire distributed to both the students and advisors. The students who joined inauguration period were given questionnaire and those who have passed thesis examination are interviewed. Both questionnaire and interview are used to know the students' background knowledge and interest on scientific article writing as well as finding problems in writing research article. The questionnaire and interview are then confirmed with the advisors.

Need analysis on students' questionnaire is done by recapitulating questionnaire distributed to undergraduate students. The table shows that definition and constituent of research article is necessary (no. 1 to 5), structure of 
research article is important (no. 6 to 7), guidance of advisor is needed (no. 8), course on research article is urgent necessity (no. 9), characteristics of research article are great consideration (no. 10), and ways to change thesis into research article is a vital prerequisite (no. 11).

While the result of scientific article structure shows that there are some different scores in each students' writing. The first part is tittle. The students' scores in title is four to five. It is meant all students has no problem in writing the title. The second part is abstract. The students' score in abstract reaches six to ten. The third part is introduction. The students' score in introduction approximates four to eight teen. The fourth part is research method. The students get twelve to twenty score in research method. The fifth part is result of the study. The students achieve six to ten score in result of the study. The next part is discussion. The students' score is four to eighteen. For the last part--closing, the students' get two until five score. By referring to the previous paragraph, the students were keen on writing title based on the number of words and the variable of research. In writing structure of abstract, there is only a student who did not follow the guideline. The other four students were confused in writing the introduction of article. In writing research method, there were seven students had problem in exploring the sample/subject of the research and source of data. None of the students had problem in exploring the result of the study. Unfortunately, two of them are confused in writing discussion, especially how to construct or modify theory. In closing the article, five students do not aware the necessity of suggestion in article.

Need analysis is done to figure out the students' problem that accurate clarification can be conveyed. In consideration of need analysis, a table is then prepared for tagging the questionnaire distributed to the students. The result of students' questionnaire is categorized into draft of syllabus (see table 3).

Table 3. Categorization of Students' Questionnaire into Draft of Syllabus

\begin{tabular}{|c|c|}
\hline Students' Questionnaire & Draft of Syllabus \\
\hline $\begin{array}{l}\text { Definition and constituent of research article is } \\
\text { necessary }\end{array}$ & The importance of scientific writing \\
\hline Structure of research article is important & The structure of scientific writing \\
\hline Guidance of advisor is needed & The style of scientific writing \\
\hline Course on research article is urgent necessity & The importance of scientific writing \\
\hline Characteristics of research are great consideration & The characteristics of scientific writing \\
\hline $\begin{array}{l}\text { Ways to change thesis into research article is a } \\
\text { vital prerequisite }\end{array}$ & The structure of scientific writing \\
\hline
\end{tabular}




\section{Design}

This phase maps the course of Scientific Writing syllabus which has been planned based on the Analysis. The analysis was done to figure out the students' problem that can be considered in designing the syllabus. After categorizing students' questionnaire into draft of syllabus, the blueprint is then designed. The designed blueprint was then conformed to experts to have suggestion in order to revise the draft. The draft designed after being revised based on the expert's suggestion is in table 4 below.

Table 4. Draft of Syllabus (revised)

\begin{tabular}{l|l}
\hline Students' Questionnaire & Draft of Syllabus \\
\hline Definition and constituent of research article is & The importance of scientific writing \\
necessary & \\
$\begin{array}{l}\text { Course on research article is urgent necessity } \\
\text { Structure of research article is important }\end{array}$ & The structure of scientific writing \\
$\begin{array}{l}\text { Ways to change thesis into research article is a } \\
\text { vital prerequisite }\end{array}$ & \\
Guidance of advisor is needed & \\
Characteristics of research are great consideration & The style of scientific writing \\
\hline
\end{tabular}

\section{Development}

In this phase, the blueprint of scientific writing syllabus is completed. The draft of blueprint includes nine points-course identity, competence, learning outcome, indicators, learning method, evaluation, main topics, instructional media and references. Those points are written based on the form of syllabus designed by the institution in which all lecturers must follow. The blueprint is corroborated to be considered as draft of Scientific Writing Syllabus. The documented draft of syllabus needs to be authenticated as apposite draft. Consideration on having apposite draft, it is necessarily proposed to be validated by expert on the succeeding step. The draft to be authorized by expert is displayed in table 5 .

Subject/credit hour : Scientific Writing 2 (two)

Course Description : Introduce the students with the concept and technique to compose research article 
Table 5 Draft of Scientific Writing Syllabus

\begin{tabular}{|c|c|c|c|c|}
\hline Competence & $\begin{array}{l}\text { Learning } \\
\text { Outcomes }\end{array}$ & Indicator & Learning Method & Evauation \\
\hline $\begin{array}{l}\text { Knowledge: } \\
\text { Understanding and } \\
\text { applying the way } \\
\text { of expressing } \\
\text { ideas } \\
\text { (communicating) } \\
\text { through written } \\
\text { media in } \\
\text { com[posing article }\end{array}$ & $\begin{array}{l}\text { Can show the skill } \\
\text { in explaining and } \\
\text { applying article } \\
\text { composition }\end{array}$ & $\begin{array}{l}\text { Explanation about } \\
\text { Scientific writing }\end{array}$ & $\begin{array}{l}\text { QDiscussion } \\
\text { ¿Writing practice } \\
\text { (drill on writing } \\
\text { research article) }\end{array}$ & $\begin{array}{l}\text { Assignment } \\
\text { Midterm } \\
\text { Final test } \\
\text { Participation }\end{array}$ \\
\hline $\begin{array}{l}\text { Skill: } \\
\text { Having skill in } \\
\text { expressing ideas } \\
\text { (communicating) } \\
\text { through written } \\
\text { media in article } \\
\text { writing }\end{array}$ & & $\begin{array}{l}\text { Composing coherence } \\
\text { and cohesive article }\end{array}$ & & \\
\hline Main Topics & & Instructional Media & \multicolumn{2}{|l|}{ References } \\
\hline $\begin{array}{l}\text { 1.The importance o } \\
\text { 2.The characteristic } \\
\text { 3.The structure of } s \\
\text { 4.The style of scien }\end{array}$ & $\begin{array}{l}\text { scientific writing } \\
\text { of scientific writing } \\
\text { ientific writing } \\
\text { fic writing }\end{array}$ & $\begin{array}{l}\text { International journal } \\
\text { National journal } \\
\text { International } \\
\text { Proceeding } \\
\text { Other resources }\end{array}$ & \multicolumn{2}{|c|}{$\begin{array}{l}\text { 1. (Slade, 2000) Form and style: Research } \\
\text { paper, reports and theses. Beijing: Foreign } \\
\text { Language Teaching and Research Press. } \\
\text { 2. Whitaker, Ann.Academic Writing Guide. } \\
\text { Bratislava, Slovakia : City University of } \\
\text { Seattle, 2009. } \\
\text { 3. (Mack, 2018). How to Write a Good } \\
\text { Scientific Paper. Washington: SPIE } \\
\text { 4. Some sources from social media or other } \\
\text { references }\end{array}$} \\
\hline
\end{tabular}

\section{Implementation}

Implementation is done for the sake of gaining applicable product. Thus, validating scientific writing course is implemented in this phase. In this case, the validity of product is obeyed that validation sheet is distributed to the expert and collaborator. This phase is held to make sure the quality and validity of Scientific Writing Syllabus. The draft designed in Development phase is evaluated based on experts' suggestion. There were four topics included in the draft, then the experts suggested to give one more topic-publishing scientific writing. By publishing, the students can express their idea for specific contribution. In conclusion, there are five topics to be concluded in Scientific Writing syllabus. By the experts' suggestion, the draft of Scientific Writing syllabus is displayed in the table 4.5 as follow. 
Table 6. Draft of Scientific Writing Syllabus

\begin{tabular}{ll}
\hline Students' Questionnaire & Draft of Syllabus \\
\hline $\begin{array}{l}\text { Definition and constituent of research article is } \\
\text { necessary }\end{array}$ & The importance of scientific writing \\
$\begin{array}{l}\text { Course on research article is urgent necessity } \\
\text { Structure of research article is important } \\
\text { Ways to change thesis into research article is a } \\
\text { vital prerequisite }\end{array}$ & The structure of scientific writing \\
$\begin{array}{l}\text { Guidance of advisor is needed } \\
\text { Characteristics of research are great consideration } \\
\text { The publication of Scientific Writing }\end{array}$ & $\begin{array}{l}\text { The style of scientific writing } \\
\text { The characteristics of scientific writing }\end{array}$ \\
\hline
\end{tabular}

\section{Evaluation}

Evaluation is done on every step in designing the syllabus. It is also the last phase of Analyze, Design, Develop, Implement and Evaluate model which is done to ensure the worthiness and applicability of the product-Scientific Writing Syllabus. There are some revisions to be final product of Scientific Writing syllabus. The revisions are done after having collaborator discussion and experts' proposition. There is a proposition from the experts-encourage the students to publish research articles. In sum, the final product to be demonstrated must be appropriate to undergraduate students in scientific writing course-syllabus of Scientific Writing. The product then presents novelty in teaching-learning English, predominantly writing skill. In approving table 4.5, recommended draft of Scientific Writing Syllabus is presented in table 7. One of revision from discussion and experts' proposition is the point of main topics. The main topic must be added, such as: the publication of scientific writing. The experts' advice was based on the necessary of publishing scientific writing that writer's ideas can give comprehensive contribution. 
Table 7. Recommended Draft of Scientific Writing Syllabus

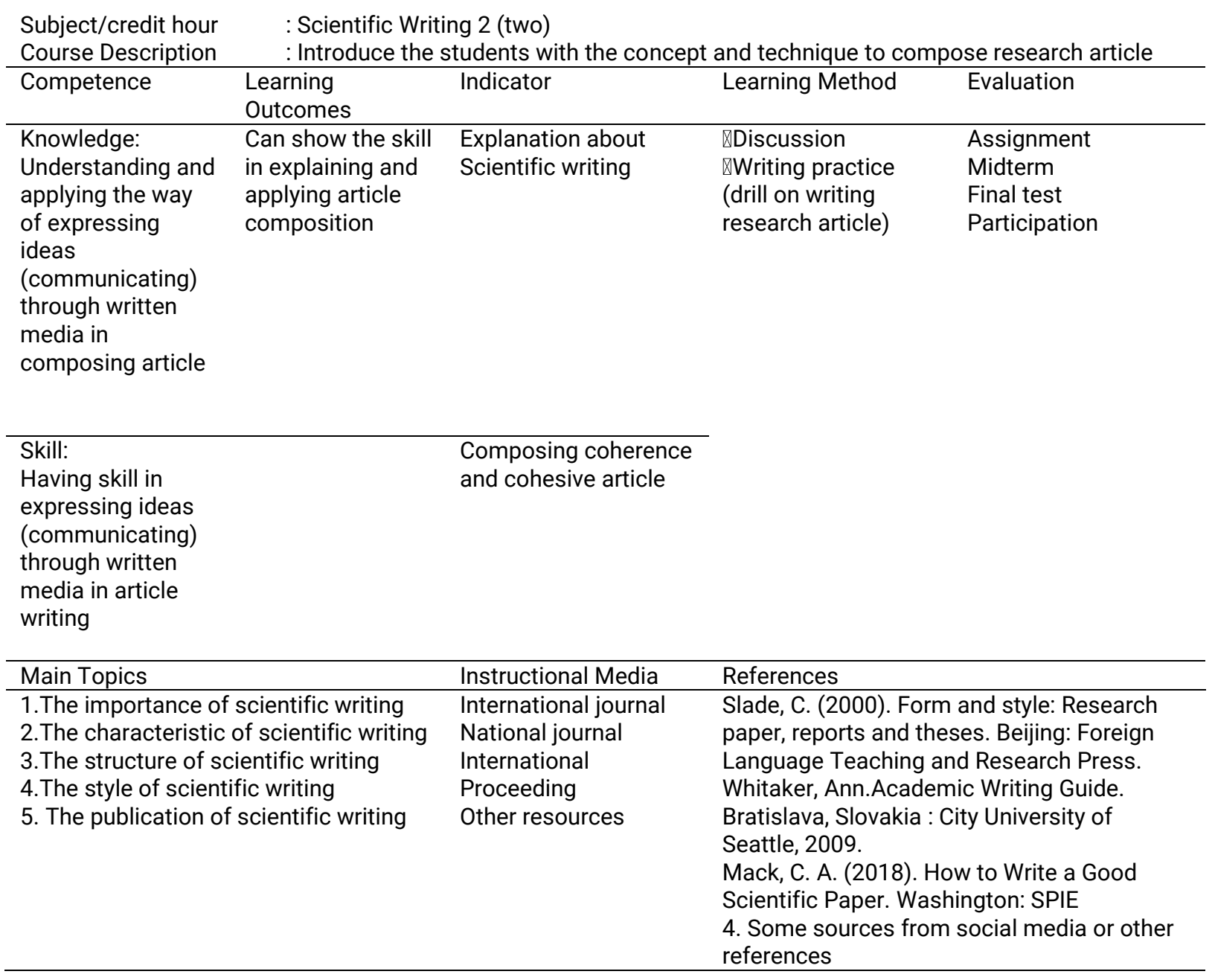

\section{Discussion}

For the sake of having better achievement in English writing, this study has aim to design Scientific Writing syllabus for the fifth semester of undergraduate students by using Analyze, Design, Develop, Implement and Evaluate model. The syllabus is engaged to furnish undergraduate students with research article writing. In order to have applicable syllabus, Analyze, Design, Develop, Implement and Evaluate is functional step in designing it. As an approach of Design and Development Research, the five steps of Analyze, Design, Develop, Implement and Evaluate model are implemented. The steps are Analyze, Design, Develop, Implement, and Evaluate with evaluation process on every step.

This study proves that Analyze, Design, Develop, Implement and Evaluate model can make an operative scientific writing syllabus. This model helps the 
lecturers to create appropriate syllabus for students by considering students' need analysis. The implementation is in line with Branch's (2010) interpretation on the use of Analyze, Design, Develop, Implement and Evaluate model. He views that the use of Analyze, Design, Develop, Implement and Evaluate model for the sake of learning achievement is appropriate since it is the concept of product improvement to be implemented for persistent learning environment. He explains further that the concept of Analyze, Design, Develop, Implement and Evaluate model is simple but completed with some stimuli that makes it operative. Analyze, Design, Develop, Implement and Evaluate model of Dick and Carey (2015) is used in developing Scientific Writing syllabus. The use of Analyze, Design, Develop, Implement and Evaluate model is has been proven in designing instruction (Bello, H., \& Aliyu, 2012; Nadiyah, R. S., \& Faaizah, 2015; Ozdilek, Z., \& Robeck, 2009), in designing media as well as ease the course builder to act and build multimedia (Hidayanto, D. R., Munir, Rahman, E. F., \& Kusnendar, 2017; Wang, S.-K. \& Hsu, 2009) In this study, Analyze, Design, Develop, Implement and Evaluate model is not used to design either instruction or media but create a syllabus that meets the problem solving of undergraduate students' difficulties. Actually, it is complex one in designing scientific writing syllabus.

There are some revisions to be final product of Scientific Writing syllabus. Finally, there are some significant topics in designing scientific writing syllabus by concerning undergraduate students' problem. There are five noteworthy topics designed, mainly: a) the importance of scientific writing, b) the characteristics of scientific writing, c) the structure of scientific writing, d) the style of scientific writing, and e) the publication of scientific writing. The last topic-publication, is meant to encourage the students in publishing research articles on journal, particularly on the credible one. The topics should be major concern in scientific writing syllabus.

\section{Conclusion}

Based on the research result, there are some significant topics in designing scientific writing syllabus by concerning undergraduate students' problem. There are five noteworthy topics designed-the importance of scientific writing, the characteristics of scientific writing, the structure of scientific writing, the style of 
scientific writing, and the publication of scientific writing. Analyze, Design, Develop, Implement and Evaluate model can be implemented in designing syllabus which appropriate with the students' problem. It is better for lecturers to take Analyze, Design, Develop, Implement and Evaluate model in designing syllabus. However, the Implementation step can be done by applying the product in class. By implementing the product in writing class then 'The product is significantly applicable' is proven. Readers and future researcher can implement Analyze, Design, Develop, Implement and Evaluate model in different field such as instructional design as has been done by practitioner and scholars.

\section{References}

Bailey, S. (2015). Academic Writing for International Students of Business (2 ed.). Routledge.

Beckett, G. H., \& Gonzalez, V. (2004). Content-based ESL Writing Curriculum: A Language Socialization Model. Journal of Research and Practice, 2(1), 161175.

Bello, H., \& Aliyu, U. O. (2012). Effect of "Dick and Carey instructional model"on the performance of electrical/electronics technology education students in some selected concepts in technical colleges of northern Nigeria. International Research Journals Educational Research, 3(3), 277-283.

Branch, R. M. (2010). Instructional design: The ADDIE approach. Instructional Design: The ADDIE Approach. Athens, GA: Springer.

Dick, W., Carey, L., \& Carey, J. O. (2015). The Systematics Design of Instruction. South Florida: Pearson. South Florida: Pearson.

Elliott, S. L., Fischer, B. A., Grinnell, F., \& Zigmond, M. J. (2015). Perspectives on Research Integrity. Washington, DC: ASM Press.

Glasman-Deal, H. (2010). Science Research Writing for Non Native Speakers of English. London: Imperial College Press.

Han, Y. (2013). An analysis of current graduation thesis writing by English majors in independent institute. English Language Teaching, 7(1), 120-127.

Hidayanto, D. R., Munir, Rahman, E. F., \& Kusnendar, J. (2017). The Application of ADDIE Model in Developing Adventure Game-based Multimedia Learning to Improve Students' Understanding of Basic Programming. In ICSI Tech (hal. 307-312).

Irvin, L. L. (2010). What Is "Academic" Writing?. Writing Spaces: Readings on Writing. Brackenberry: Parlor Press.

Mack, C. A. (2018). How to Write a Good Scientific Paper. Washington, D: SPIE.

Miles, M. B., Huberman, A. M., and Saldana, J. (2014). Qualitative Data Analysis: A Methods Sourcebook and the Coding Manual for Qualitative Researchers. 
Thousand Oaks, CA: SAGE.

Nadiyah, R. S., \& Faaizah, S. (2015). The Development of Online Project Based Collaborative Learning using ADDIE Model. Procedia - Social and Behavioral Sciences, 195, 1803-1812.

Ozdilek, Z., \& Robeck, E. (2009). Optional Priorities of Instructional Designers Analyzed within the Steps of the Addie Instructional Design Model. Procedia Social and Behavioral Sciences. Procedia - Social and Behavioral Sciences, 1(1), Pages 2046-2050.

Plomp, T. (2010). Educational Design Research: an Introduction. In T. Plomp \& N. Nieven (Ed.), An Introduction to Educational Design Research. Enschede.

Richey, R. C., \& Klein, J. D. (2009). Design and Development Research. New York: Routledge.

Slade, C. (2000). Form and Style: Research Paper, Reports and Theses. Beijing: Foreign Language Teaching and Research Press.

Tang, W.-L. Tsai J.-T. \& Chen, C.-H. (2017). Research on ADDIE Model Applied to Develop the Digital Material of MCRLC in Taiwan. In SICE Annual Conference. In Proceedings of the SICE Annual Conference (hal. 561-563). Kanazawa: Kanazawa University.

Wang, S.-K. \& Hsu, H.-Y. (2009). Using the ADDIE Model to Design Second Life Activities for Online Learners. TechTrends, 53(6), 76-81.

Wang, Y., \& Guo, M. (2014). A Short Analysis of Discourse Coherence. Journal of Language Teaching and Research, 5(2), 460-465. 
This page intentionally left blank. 